\title{
The Emergence of an Economic-Security Nexus and the Diversity of FTA Linkage Strategies in East Asia*
}

\author{
Seungjoo Lee**
}

\begin{abstract}
While aggressively embracing free trade agreements (FTAs) in general, East Asian countries have incorporated security and political factors in promoting FTAs under the swiftly shifting regional economic and security environments, epitomized by the end of the Cold War, the Asian financial crisis, and the intensifying Sino-Japanese rivalry. Therefore, a sole focus on economic factors would fail to shed light on East Asian strategies for linking FTAs and security. While FTAs have mushroomed in East Asia since 2000, East Asian countries have pursued FTAs not merely to increase their economic interests. In many cases, they have attempted to link FTAs to broader security considerations. However, they have demonstrated markedly diverse ways of linking FTAs and security, depending on their primary economic and security imperatives as well as their domestic political situations.
\end{abstract}

Keywords: economic-security nexus, FTA, linkage strategy, Korea, China, Japan, Singapore

\section{INTRODUCTION}

Economic interdependence among East Asian countries has substantially increased since the mid-1980s. Nonetheless, East Asian countries pursued informal networking in the region until the late 1990s, rather than seeking formal integration (Hemmer \& Katzenstein, 2002). However, since 2000 East Asian countries have demonstrated greater interest in institutionalizing the region as they actively undertook free trade agreement (FTA) negotiations. Major countries in East Asia have engaged in multiple FTA deals over the last decade. Despite its belated jump onto the FTA bandwagon,

\footnotetext{
* This work was supported by a National Research Foundation Grant funded by the Korean government (NRF-2010-330-B00027).

** Seungjoo Lee is a professor of Department of Political Science and International Relations, Chung-Ang University. E-mail: seungjoo@cau.ac.kr
}

Manuscript received February 10, 2012; out for review February 21, 2012; review completed March 15, 2012; accepted March 29, 2012.

The Korean Journal of Policy Studies, Vol. 27, No. 1 (2012), pp. 109-129.

(C) 2012 by the GSPA, Seoul National University 
China quickly completed nine FTAs, with another five deals under negotiation (MOFCOM, 2012). Departing from its longstanding emphasis on informal networks in the region, Japan has also finalized 12 FTAs and is currently negotiating four more (MOFA, 2012). South Korea has completed eight FTA deals with 45 countries, including the European Union (EU) and Association of Southeast Asian Nations (ASEAN), with seven FTAs under negotiation (MOFAT, 2011). Singapore, most enthusiastic about FTAs in East Asia, has concluded 20 FTAs, of which 18 are in effect and two are signed (Government of Singapore, 2010). This change is largely seen as an attempt to transform deepened economic integration into more institutionalized arrangements (Aggarwal \& Koo, 2007; Pempel, 2006).

What motivated East Asian countries to make such a dramatic turnaround? A sole focus on economic factors would fail to shed light on East Asia's greater appetite for FTAs. East Asian countries have incorporated security and political factors in promoting FTAs. Swift shifts in regional economic and security environments that are epitomized by the end of the Cold War, the Asian financial crisis, and the intensifying Sino-Japanese rivalry are the considerations that East Asian countries took into account in seeking FTAs. With this backdrop, the proliferation of FTAs in East Asia is a good example of the way in which an economic-security nexus is forged (Pempel, 2010).

Rivalry between China and Japan shows the way in which security concerns profoundly affect both countries' FTA strategies. The dual dynamics of competition and cooperation are incorporated into both countries' FTA strategies. On the one hand, neither country attempted to impede the other's vital interests. Japan has avoided signing an FTA with Taiwan despite urgent calls from the Taiwanese side, assuming that doing so would offend Beijing. On the other hand, both countries' aspirations for regional leadership hampered the formation of a China-Japan FTA, despite enormous economic benefits. The rivalry also militates against the formation of an East Asian FTA that could unite countries in the region in one unified free trade area. Instead, China and Japan competed to court Southeast Asian countries as FTA partners. That is, both countries' strategic considerations, combined with collective memory of the historical past, clashes of national identity, and the eruption of territorial disputes, significantly hinder efforts to form a China-Japan FTA as well as an East Asian FTA (Ikenberry \& Mastanduno, 2003; Katzenstein, 1997; Pempel, 2005).

The dynamic evolution of an economic-security nexus has substantially altered regional institutional dynamics. In this regard, the economic-security linkage reflected in an FTA may serve as a double-edged sword in institutionalizing East Asia cooperation. Whereas institutionalized cooperation spurred by FTAs is expected to substantially allay security concerns in East Asia, political and security considerations are likely to hinder the formation of a region-wide FTA in East Asia. 
This paper explains divergent patterns of economic-security nexus by exploring East Asian countries' FTA strategies. It addresses the following issues: How did external factors, such as the collapse of the Cold War structure in East Asia and the Asian financial crisis of 1997, affect East Asian countries' strategies of linkage between FTA and security alliance? What security factors are responsible for shaping the linkage strategy? And how does the interplay of external and domestic factors influence the evolution of East Asian countries' linkage strategy?

The remainder of this paper is organized as follows: The next section provides a brief overview of the existing literature on the security effects of FTAs. Subsequent sections explore how East Asian countries-China, Japan, Singapore, and South Korea-have implemented different strategies for linking economic and security matters in promoting FTAs. The conclusion draws some theoretical and practical implications arising from the main findings of the paper.

\section{ECONOMIC-SECURITY NEXUS IN EAST ASIA}

A vast literature exists of attempts to explain crucial features of East Asian countries' FTAs such as the economic, political, and security determinants of FTA policy (Aggarwal, 2006; Katada \& Solis, 2007). While it is generally argued that an economic "domino effect" spurred countries to rush to FTAs to evade negative economic impacts (see Baldwin, 1993), it is also worth examining the way in which government policy makers also take traditional security and strategic considerations into account in negotiating FTAs (Feinberg, 2003; Ravenhill, 2008). For example, great powers may sign FTAs to reward military allies and strengthen their security status. In this view, countries are more likely to form FTA networks with allies rather than selecting FTA partners purely on the basis of economic benefits. The US government is explicit in linking foreign economic and security policy, as demonstrated by the US-Israel and US-Jordan FTAs. The "securitization" of FTA policy has further accelerated in the post-9/11 era (Higgott, 2004). In East Asia, the US-Singapore FTA was the first obviously securitized FTA. From the US perspective, it was a reward for Singapore's provision of military facilities.

Building on the prior literature, this paper explores how East Asian countries incorporate security and strategic factors into FTA policy-making. The common traits shared by East Asian countries — such as a tendency to sign FTAs with minor economic partners, the limited coverage of FTAs, and weak evidence of an active business lobby - are indicative that the proliferation of FTAs in East Asia is driven not just by economic interests but also by political and strategic domino effects (Ravenhill, 2010). 
The paper also sheds light on how and why great and small powers pursue immensely different linkage strategies. In terms of trade share covered by FTAs, East Asian countries show quite different patterns. Countries such as Indonesia (66.3 percent), Singapore (65.9 percent), Thailand (55 percent), and Viet Nam (53.7 percent) have a higher share than the world average. By contrast, the ratio is considerably lower than the world average in major countries such as China (19.2 percent), Japan (16.5 percent), and Korea (14.8 percent). If FTAs recently signed are included, the ratio for China and Japan changes slightly to 19.4 percent and 17.6 percent, respectively. The ratio for South Korea rises to 35.1 percent if the Korea-EU FTA and Korea-US (KORUS) FTAs are included. But even this ratio is lower than that of major countries in other regions such as Germany (74.8 percent), France (76 percent), the United Kingdom (63.9 percent), and the United States (37.7 percent) (Institute of International Trade of Korea, 2011).

This difference between great powers and small countries stems from the different patterns of linkages between economy and security. Whereas China and Japan did not sign bilateral or trilateral FTAs in fear of their negative security externalities, despite the rapid growth of bilateral and trilateral trade for the last decade, small countries are more active in attracting great powers to maximize economic gains as well as to reduce their security vulnerabilities (on the security effects of FTAs, see Mochizuki,

Figure 1. Share of Trade Covered by FTAs

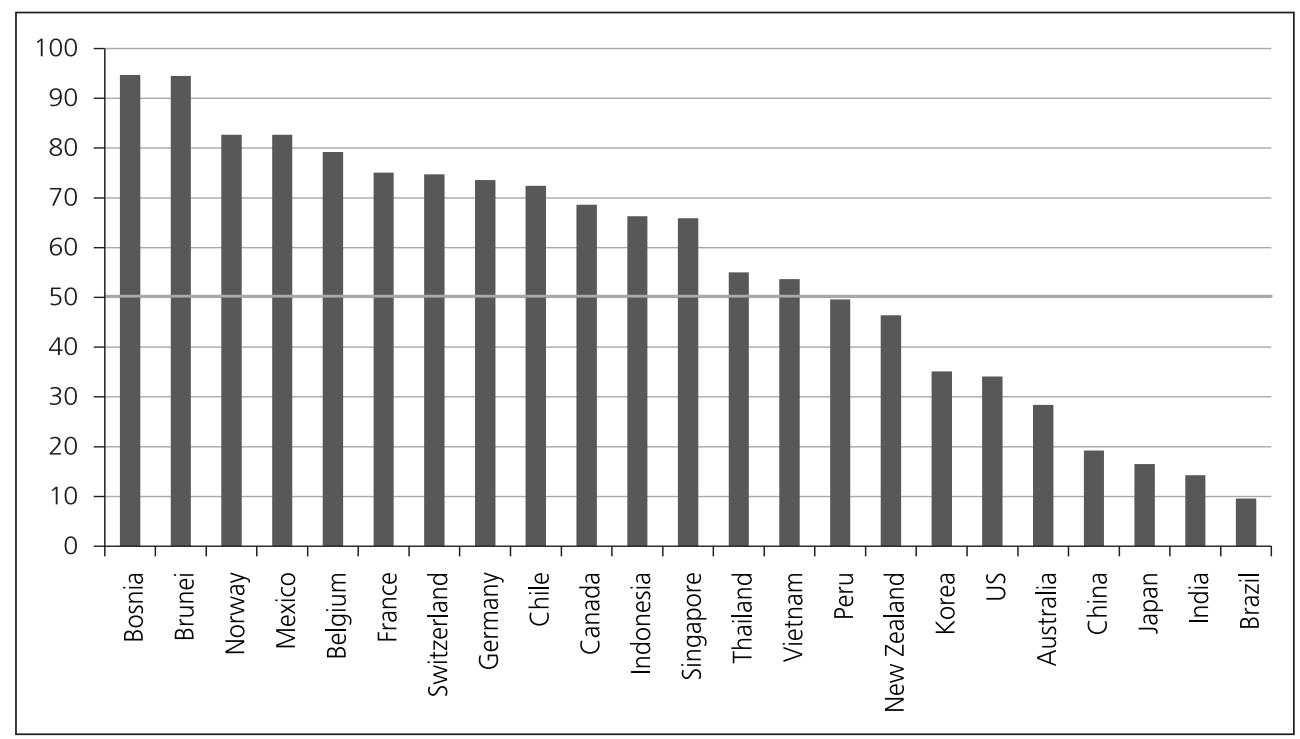

Note: Horizontal line indicates world average (49.2 percent).

Source: Institute of International Trade of Korea, 2011. 
2009).

From a broader security perspective, great powers tend to seek FTAs as a means to balance against the target state. China and Japan competed to attract regional countries to their sides to (re)design the regional institutional architecture to exclude the other. Both countries' rush to sign an FTA with ASEAN vividly shows this dynamic. Despite greater economic gains from a China-Japan FTA, strategic considerationsthe desire to take the initiative in regional institution building - pushed them to court ASEAN competitively.

By contrast, small countries are inclined to sign FTAs with bigger partners for diplomatic and security reasons. The fear of exclusion and security vulnerability forces small countries to engage in FTA negotiations with great powers (Gruber, 2000). Small countries surrounded by regional powers prefer great powers outside the region as their FTA partners. Small states that do not want regional institutions to be dominated by one great power are also likely to pursue FTAs with other great powers (Grieco, 1997). With this backdrop, small countries sometimes enter into FTA negotiations with bigger countries although they may run the risk of having to make more concessions.

\section{CHINA: PREEMPTIVE AND STRATEGIC LINKAGE STRATEGY}

Political and security considerations take a central importance in Chinese FTA policy-making. Some analysts argue that security motivation in FTAs looms even greater in China than in the United States (deLisle, 2006). Chinese Communist Party (CCP)'s political dominance and centralized policy-making structure, led by the Ministry of Foreign Affairs (MOFA), greatly helped China carry out its linkage strategy in a coherent way, compared to other East Asian countries that often faced political gridlock in garnering domestic support on FTA policy (Kwei, 2006). It is against this backdrop that China could utilize FTAs as an instrument to achieve foreign and security policy goals. ${ }^{1}$ FTAs effectively served the Chinese government's objectives not just to expand its sphere of influence in the international arena, but also to launch its charm offensive in East Asia (see Kurlanzick, 2008).

China's FTA policy was undoubtedly influenced by Japan's first move to sign an FTA with Singapore. For China, Japan's initial move was seen as an attempt to establish

1. In addition, viewing securing access to natural resources as in its security interest, China aggressively embarked on FTA negotiations with resource-abundant countries in the Middle East and Africa. 
regional leadership in East Asia by encircling China. The Chinese government strove to derail the Japanese endeavor by embarking on FTA negotiations with its neighboring countries (Yang \& Heng, 2010). In addition, it was of paramount importance for China to prevent Southeast Asian countries from aligning with the US efforts to contain China (Wesley, 2008).

In economic terms, China made a great deal of effort to assure its neighboring countries that although the current economic structures of China and ASEAN are competitive, their economic interdependence can make them complementary in the long run. The Chinese government further argued that the China-ASEAN FTA will facilitate deep economic integration, while enhancing diplomatic and political ties as well.

China executed strategic and preemptive linkages in the course of the negotiations to accommodate Southeast Asian countries' interests. First, China has made tremendous efforts to assure Southeast Asian countries that its rise would remain peaceful and would not conflict with their interests. To allay Southeast Asian countries' security concerns, in 2002, China signed the ASEAN Code of Conduct on Disputes in the South China Sea as a token of its willingness to settle territorial disputes peacefully. With the signing the Treaty of Amity and Cooperation of Southeast Asia in 2003, China accelerated its charm offensive to signal that it would abide by long-standing dispute settlement practices firmly established by Southeast Asian countries (Zhao, 2010). China's efforts succeeded, at least to some degree, in ameliorating Southeast Asian countries' worries about a China threat. The Joint Declaration on Strategic Partnership for Peace and Prosperity, signed by China and ASEAN, illustrated this and stated that the signing of the Treaty of Amity and Cooperation "demonstrated that the political trust between the two sides notably enhanced" (ASEAN, 2009).

Second, China aptly took advantage of its developing country status at the World Trade Organisation (WTO), as the WTO stipulates that developing countries can sign an FTA based on the enabling clause of the General Agreement on Tariffs and Trade (GATT). Under these more lenient rules, China was not required to liberalize "substantially all trade" and could exclude sensitive sectors, such as banking and telecommunications, from liberalization. The developing country status put China in a better position to accommodate Southeast Asian countries' interests, compared to Japan, which had to abide by the stricter GATT Article XXIV to sign FTAs (Solis, 2009).

The Early Harvest Program was another centerpiece of Chinese linkage strategy. The Chinese government offered early liberalization of agricultural imports from Southeast Asian countries to accelerate the implementation of the China-ASEAN FTA. It was designed to reduce Southeast Asian countries' concern about negative consequences of the China-ASEAN FTA. The provisions of the Early Harvest Program 
were immediately included in the Framework Agreement, although it was expected that farmers in southern provinces would suffer. Commenced in January 2004, the program put 562 agricultural items on the list of early liberalization (ASEAN, 2010). As shown in table 1, tariffs on items under the EHP were to be eliminated within two years.

Table 1. Early Harvest Program in China-ASEAN FTA

\begin{tabular}{l|c|c|c}
\hline \multicolumn{1}{c|}{ Product category } & $\begin{array}{c}\text { Not later than January } \\
2004\end{array}$ & $\begin{array}{c}\text { Not later than January } \\
2005\end{array}$ & $\begin{array}{c}\text { Not later than January } \\
2006\end{array}$ \\
\hline $\begin{array}{l}\text { MFN tariff rates } \\
\text { higher than 15\% }\end{array}$ & $10 \%$ & $5 \%$ & $0 \%$ \\
\hline $\begin{array}{l}\text { MFN tariff rates } \\
\text { between 5\% and 15\% }\end{array}$ & $5 \%$ & $0 \%$ & $0 \%$ \\
\hline $\begin{array}{l}\text { MFN tariff rates lower } \\
\text { than 5\% }\end{array}$ & $0 \%$ & $0 \%$ & $0 \%$ \\
\hline
\end{tabular}

Note: MFN refers to most favored nation.

Source: ASEAN, 2010.

It is against this backdrop that China proposed the China-ASEAN FTA at the ASEAN-China Summit in 2000 under Premier Zhu Rongji's initiative. By proposing the China-ASEAN FTA, the Chinese government aimed to ameliorate Southeast Asian countries' concerns about the potential impact of China's WTO accession on their economies. In negotiating the FTA with ASEAN, China's political leadership prioritized overall strategic and security interests over narrow economic interests. China's centralized FTA policy-making made preemptive and strategic moves possible. Under the guidance of the CCP, the MOFA as a lead agency in FTA policy-making successfully minimized potential conflicts among government ministries. This institutional feature allowed China to make unilateral concessions to Southeast Asian countries, despite the Ministry of Agriculture's concern about economic loss in the agricultural sector. ${ }^{2}$ The Chinese made a preemptive move to conclude an FTA with ASEAN as a whole, assuming that such a move would put China in a better position to compete with Japan and exclude the United States from regional leadership (Cai, 2004). China's linkage strategy is in stark contrast to Japan's FTA strategy, which simultaneously pursued multiple FTAs with individual Southeast Asian countries.

2. Jiang (2010) argues that China's FTA policy-making has become less strategic and coherent. Since the Ministry of Commerce, with expertise in trade negotiations, took over the MOFA's position as lead agency, economic considerations have become more important. 


\section{JAPAN: REACTIVE LINKAGE STRATEGY}

Japan's FTA policy also has security and strategic drivers. However, Japan's linkage strategy is essentially reactive because the Japanese government is domestically constrained in linking economy and security. Although its political power has declined, the iron triangle formed by farmers, zoku politicians with keen interests in protecting the agricultural sector in the LPD, and the Ministry of Agriculture still was able to put mounting pressure on the Japanese government. Furthermore, unable to dispel neighboring countries' suspicion of its strategic intentions, which were rooted in historical memories, Japan was restrained in taking a leadership role in East Asia.

Despite this political and institutional gridlock, the Japanese government suddenly departed from its traditional policy stance to pursue FTAs. China was a core reason for this change. In the 1990s, experts and commentators argued that Japan was content to wield "network power" stemming from its widespread production networks in East Asia and did not seek leadership in formally institutionalizing relations in the region. However, after 2000, the rise of China profoundly changed Japan's strategic calculus. Since its accession to the WTO, China's economic engagement with Southeast Asian countries has steadily increased. In addition, the proliferation of FTAs in East Asia as well as China's aggressive FTA policy encouraged Japan to rethink its traditional policy.

However, in contrast to China's proactive and coherent linkage strategy, Japan's linkage strategy is inherently reactive and defensive (Sally, 2006). Japan's decision to embark on FTA negotiations with ASEAN is a good case in point. The Japanese government's institutional arrangements, coalitions among key players, and pattern of interaction combined to shape the reactive nature of Japanese FTA policy. The pattern of political coalition has become complicated as voters became ambivalent in identifying and articulating their interests and preferences about trade. The interests of the agricultural sector, which had inspired staunch anti-liberalization movements, diverged between traditional protectionists and internationalists. The interests of the manufacturing industry were not monolithic, either, as they were divided between highly competitive multinational corporations and small and medium-size enterprises (Krauss \& Naoi, 2010).

Within the government, the Ministry of Economy, Trade, and Industry (METI) succeeded in playing a pivotal role in launching the FTA drive only after it overcame the skepticism of the Ministry of Foreign Affairs, which perceived METI's initiative with respect to FTAs as encroaching on its own mandate. However, the diversified FTA policy-making structure and strong agricultural opposition inherently limited the Japanese government's ability to design a coherent linkage strategy. The four-ministry 
system in which the Ministry of Foreign Affairs (MOFA), METI, Ministry of Finance (MOF), and Ministry of Agriculture, Forestry, and Fisheries (MOAFF) are involved in FTA policy-making requires time-consuming consultations and discussions among them, because each ministry has a veto. ${ }^{3}$ This system of FTA policy-making was a source of gridlock that prevented the Japanese government from taking a proactive posture in promoting FTAs.

Given this situation, Japan chose Singapore as its first FTA partner mainly because agriculture would be excluded from this FTA (Terada, 2009). Since then, Japan has proceeded with FTA negotiations with individual Southeast Asian countries. In the face of mounting pressure from the agricultural sector, the Japanese government thought that this strategy would serve Japan's interests better, because the Japanese government would be able to take advantage of its asymmetric power in dealing with individual Southeast Asian countries (Lee, 2009).

Alarmed by China's preemptive move, however, Japan was under pressure to court Southeast Asian countries and compete for regional leadership. Nonetheless, Japan's negotiations with ASEAN were riddled with conflicts and delays. Although Japan and ASEAN agreed in November 2002 to launch negotiations, and started preliminary talks in 2004, formal negotiations did not start until April 2005, because the two parties could not agree on the coverage and the schedule for tariff reductions or removals.

The sluggish progress of the FTA negotiations, hampered by bureaucratic rivalry, ultimately led to Prime Minister Koizumi's intervention in FTA policy-making. The Council on Economic and Fiscal Policy was a political arm of the Koizumi government in its drive to firmly establish political control over bureaucrats. In FTA policy-making, in December 2003, the Koizumi government created the Council on Ministers Concerned with the Promotion of Economic Partnership to remedy the institutional barriers by increasing political control over the ministries (Lee, 2009).

Under the new policy-making structure, the Japanese government could seek regional leadership more effectively. Jolted by the China-ASEAN FTA, the Koizumi government modified its FTA strategy (Yoshimatsu, 2006). Japan initially preferred FTAs with individual ASEAN countries, and concluded agreements with seven countries by $2009 .{ }^{4}$ However, alarmed by the China-ASEAN FTA, Japan modified this strategy in 2008 to sign an FTA with ASEAN, demonstrating that Japan's FTAs are

3. It is well documented that Japan's policy-making is saddled with bureaucratic infighting as well as strong political pressure from the agricultural sector (Mulgan, 2005).

4. Terada (2011). Seven ASEAN members that currently implement an individual FTA with Japan are Singapore, Malaysia, Brunei, Viet Nam, Laos, Myanmar and Thailand. http://www .fta.gov.sg/fta_ajcep.asp?hl=38. 
not purely driven by economic factors but reflect its desire to rejuvenate its presence in the region. ${ }^{5}$ Diplomatic and security concerns led the Koizumi government to overcome domestic constraints to start a Japan-ASEAN FTA.

Japan also tried to engage with extra-regional powers. In particular, the JapanAustralia FTA was an outgrowth of Japan's strategic and security concerns. Strengthening economic ties between China and Australia clearly prompted Japan to embark on FTA negotiations with Australia. Otherwise, it was inconceivable to launch FTA negotiations with Australia, which accounts for about 10 percent of Japan's total agricultural imports, because the Japanese government still faced staunch agricultural protectionism in the domestic political arena. Departing from its reactive policy, which was heavily influenced by protectionist interests, the Japanese government decided to embark on FTA deals with a major exporter of agricultural products (Capling, 2008). The economic-security nexus became even more obvious when, in addition to the opening of the FTA negotiations, both governments announced their intention to sign a Japan-Australia Joint Declaration on Security Cooperation. The Japanese move was somewhat unexpected because Japan had not formed a formal security partnership with any countries other than the United States (Solis, 2009). Negotiations for a JapanAustralia FTA were made possible, because political security considerations spearheaded by Koizumi's leadership substantially weakened domestic constraints.

\section{SINGAPORE: LINKAGE WITH REGIONAL AND EXTRA-REGIONAL POWERS}

Singapore is most explicit in implementing a linkage strategy. Singapore is not highly motivated to push for FTAs because, with near zero tariffs, it expects limited economic gains from trade liberalization. Singapore's shift toward bilateral FTAs could be seen as its strategic response to heightened uncertainties such as the rise of regional trading agreements and shifting security relations in East Asia. Security considerations are thoroughly incorporated in the FTA strategy of Singapore, for which survival has been the foremost preoccupation since independence and "has been its credo in its foreign policy" (Leifer, 2000, p. 68). Singapore's interest in FTAs has grown not just out of economic interests but also from security considerations.

5. Japan clearly had economic motivations for this change. Because Japanese firms operate production networks in Southeast Asia, the Japanese government found it crucial to harmonize rules of origin across Southeast Asian countries to manage intra-firm trade in the region (METI, 2008). 
Singapore has attempted to link security needs to economic interdependence, hoping that an increase in economic interdependence with many countries, particularly with multiple great powers, will substantially reduce its insecurity (Pang, 2007).

Singapore's linkage strategy has unfolded in two ways. First, it has pursued bilateral FTAs. While Southeast Asia's overall economic vitality and political stability have been vital to Singapore's sustainable growth (Leifer, 2000), its policy stance toward Southeast Asia underwent a subtle evolutionary change as it attempted to transform itself into a regional hub in a wide range of industries, ranging from financial to telecommunication and transport services (Weber, 2001).

Singapore seeks bilateral FTAs with countries outside the region to expand and diversify its trading base. This necessity has dramatically increased since the Asian financial crisis in 1997, in which Singapore was frustrated with the divisions within ASEAN and with ASEAN's inability to resolve the crisis. It took four months for ASEAN to make the simple declaration that the countries in the region affected by the crisis should develop their own means of tackling the crisis. This lack of leadership in ASEAN was further aggravated by Indonesia's subsequent economic and political chaos (Business Times, January 15, 2001). Under this circumstance, the Singapore government began to seek alternative sources of stability to alleviate its vulnerability to regional turmoil.

Furthermore, surrounded by Malaysia and Indonesia, large Islamic countries that occasionally aligned in an aggressive way to pose a security threat, Singapore tried to court regional great powers as a way of reducing security vulnerability. In this regard, China and Japan are natural candidates. Singapore concluded an FTA with Japan in 2002, the first FTA between East Asian countries, and pushed for an FTA with China, which was signed in October 2008 after eight rounds of negotiation. Singapore concluded FTAs with these two regional powers individually, despite the opposition of neighboring countries, which argued that Singapore's FTA with these great powers would hurt ASEAN's unity. The Singapore government thought that attracting the two regional powers was an effective means of reducing its vulnerability.

Second, Singapore has also been active in forging ties with great powers outside East Asia. The primary motivation for this has to do with the rise of China. Although China has repeatedly stated that its peaceful rise would not be detrimental to the core interests of Southeast Asian countries, Singapore was not certain about China's intentions in the region and chose to pursue ties with extra-regional great powers. As shown in the remarks of Raymond Lim, Minister of State for Trade and Industry and Foreign Affairs, Singapore has to attract bigger extra-regional powers to anchor their presence in the region and ensure that they remain stakeholders in Southeast Asia (Straits Times, March 3, 2003). It is against this backdrop that Singapore sought a US- 
Singapore FTA even if it had to concede in some key industries such as finance (Lee, 2006). With the commencement of the US-Singapore FTA, both countries agreed to sign a strategic partnership agreement, suggesting that Singapore's policy objective was to link FTAs to security.

Both the US strategy in East Asia and Singapore's FTA policy-making structure helped the Singapore government implement the linkage strategy effectively. First, Singapore's goal was commensurate with the core interests of the United States. Throughout the post-Cold War period, the key US policy objective was to derail any power's attempt at dominating the region to the exclusion of the United States (Shirk, 2010, p. 31). The United States has consistently attempted to establish a military presence and strengthen its bilateral alliances in the region (Green, 2010, p. 36). In short, Singapore and the United States shared a common view that it is in their interests to coordinate security policies in the rapidly changing security environment in Southeast Asia (Terada, 2009).

Second, in the face of internal and external pressures for change, the Singapore government has displayed its capacity to transform the economy as well (Low, 2001). In the area of foreign economic policy, major players are the Ministry of Trade and Industry, Ministry of Foreign Affairs, Trade Development Board, Monetary Authority of Singapore, and Ministry of Communications and Information. Academics from renowned universities and research institutes, as well as business leaders, play a crucial role in making policies related to FTAs in formal and informal ways. However, the Singapore government has maintained a highly unified policy-making structure in which jurisdictional authority is centralized within a single ministry. That is, although many government agencies are involved in FTA negotiations, policy making in Singapore is primarily led by the Ministry of Trade and Industry, minimizing the potential for a bureaucratic turf war (Lee, 2006).

The Singapore government was essential in initiating and sustaining the FTA drive. This policy-making structure to some extent mirrors the highly centralized nature of the political leadership in Singapore that took the initiative in pushing for FTAs. However, one should not exaggerate the dominance of the state. While insulated from societal interests, the Singapore government managed to maintain a close relationship with the private sector, which in turn helped the government establish a channel that could facilitate information sharing between the government and the private sector. For example, business leaders such as representatives from the Association of Banks in Singapore and Neptune Orient Lines, as well as academics from the National University of Singapore and Singapore Institute of International Affairs, played a pivotal role in drawing up a feasibility report before the Ministry of Trade and Industry embarked on formal negotiations with Japan. The same was true in the case of Singapore-Korea 
FTA negotiations. In this sense, the political leadership and bureaucracy in Singapore often cooperate with business people and academics, blurring boundaries between public and private (Hamilton-Hart, 2000).

\section{SOUTH KOREA: SECURITIZATION OF THE FTA}

Korea is a unique case in that it signed an FTA with a country with which it also had a formal security alliance treaty. While the policy shift toward FTAs under President Kim Dae-jung marked a dramatic departure from South Korea's traditional trade policy, it was not until President Roh entered office in 2003 that the road map and detailed action plans for FTAs were drawn up (Lee, 2007, p. 116; Ministry of Foreign Affairs and Trade of Korea, 2006). The Roh administration consolidated Kim's FTA agenda by outlining a comprehensive road map for South Korea's multitrack FTAs. Under the road map, South Korea's FTA partners are classified into three broad groups: (1) immediate FTA partners such as Chile, Singapore, the European Free Trade Association (EFTA), and Japan; (2) medium-term FTA partners such as Mexico, Canada, ASEAN, and China; and (3) long-term FTA partners such as the United States, the EU, and India. The road map emphasized that FTAs were an important part of South Korea's goal to become an "open trading state" (Ministry of Foreign Affairs and Trade of Korea, 2006).

It was clear that in contrast to its rather peripheral status in President Kim's economic and strategic agenda, the FTA policy emerged as a core element of President Roh's foreign economic policy vision, thereby departing from his initial vision for Northeast Asian Cooperation Initiative (Lee \& Koo, 2006; Koo, 2009). A careful examination of the Roh government's FTA policy reveals two interesting anomalies. One is the lack of policy efforts to expedite an FTA among China, Japan, and South Korea, and the other is an unexpectedly early push for the KORUS FTA. One might expect rapidly rising intraregional trade and foreign direct investment (FDI) in Northeast Asia to spur South Korea to prioritize institutionalized economic cooperation with China and Japan. South Korea is likely to realize significant tangible and intangible benefits from bilateral or trilateral FTAs among the three countries. Nonetheless, the trilateral FTA has made very little progress, which is puzzling given these countries' geographic proximity and economic interdependence.

The move toward a KORUS FTA is the most illustrative example of the Roh administration's top-down and proactive FTA strategy. The Roh government suddenly revised the timetable for FTA negotiations and promulgated the FTA road map to announce its intention to start FTA negotiations with the United States. As Northeast 
Asian regionalism stagnated, the Roh government surprised the Korean public on February 3, 2006, by announcing that it would embark on FTA negotiations with the United States, becoming the first Northeast Asian country to do so. Despite South Korean filmmakers' protests, the Roh government made a surprise move in February 2006 to cut South Korea's annual screen quota limiting US film imports, removing the last hurdle to the start of KORUS FTA negotiations. ${ }^{6}$ In addition to the screen quota reduction, the Roh government also lifted the ban on US beef, proposed modifications to the pharmaceutical pricing system, and revised an automobile remissions regulation to provide a grace period for imported vehicles.

The pace of the negotiations reflected the Roh government's sincere determination to achieve the KORUS FTA. The two countries held two rounds of official talks in summer 2006, targeting March 2007 as the intended date of conclusion despite criticism of this unusually tight timetable. Beginning with the first negotiation on June 5, 2006, the two countries completed eight rounds of negotiation within eight months. Finally, on April 2, 2007, the governments of the two countries signed the KORUS FTA (MOFAT FTA Homepage, http://www.fta.go.kr). All of these measures were intended to show the South Korean government's seriousness about and commitment to a KORUS FTA (Cooper \& Manyin, 2007).

South Korea's entrance into the KORUS FTA negotiations signaled that the focus of its FTA policy has profoundly changed - from a reactive and gradualist strategy to minimize the negative effects of FTAs to a proactive and aggressive strategy aimed to maximize their benefits. What accounts for the policy shift? The Roh government pushed for the KORUS FTA, believing that it would serve both the economic and security interests of South Korea. On the one hand, the KORUS FTA will substantially increase South Korea's economic gains from liberalization of trade and investment. On the other hand, the KORUS FTA was the Roh government's hedging strategy to effectively cope with volatile strategic environments in the region by transforming a security alliance into a comprehensive alliance with the United States (Sohn \& Koo, 2011).

First, facing the failure of its strategies to make Korea East Asia's economic hub, the Roh government attempted to rejuvenate its vision by promoting the KORUS FTA. The Roh government thought that the KORUS FTA would boost South Korea's economic as well as strategic position in East Asia. Korea's deteriorating economic position in East Asia prompted the Roh government to seek FTAs with major

6. South Korea's screen quota system was designed to stem a flood of Hollywood blockbusters. South Korea cut the quota from 146 days or 40 percent reserved for domestic films to 73 days or 20 percent starting on July 1, 2006 (Chosun Ilbo, January 26, 2006). 
economies outside the region. Since 2000, South Korea's competitive advantage has seriously weakened as the industrial structures of the three countries in Northeast Asia have become more competitive. The Roh government worried that South Korea's economic position would further weaken if China or Japan concluded an FTA with the United States ahead of Korea (Moon \& Rhyu, 2010).

The Roh government believed that the KORUS FTA had the potential to alter the dynamics of US-South Korean economic relations as well as the relations between the United States, Japan, China, and South Korea. ${ }^{7}$ President Roh stated that "China is surging. South Korea is trapped between China and Japan, and thus needs to address this undesirable situation sooner rather than later. An effective way to realize this goal is to improve our country's competitive edge against China and Japan in the US market through a KORUS FTA." 8

In this sense, the KORUS FTA was an aggressive attempt by South Korea to sign an FTA with the United States ahead of China and Japan. The Roh government's policy stance was once again ascertained by the remarks of Trade Minister Kim Hyunchong, who argued, "The KORUS FTA is the key to the survival of our nation that is sandwiched between China and Japan. ... With the successful launching of the KORUS FTA, we will be able to emerge as an FTA hub in the region, as it will attract other neighboring countries to FTA negotiations with us" (Joongang Daily, April 6, 2007). In a similar vein, Yoon Young-kwan, who served as the first minister of foreign affairs and trade of the Roh administration, stressed that an FTA with the United States is a useful means to promote South Korea's role as an economic hub country in East Asia. He argued that a KORUS FTA is compatible with South Korea's globalization strategy that began in the early 1990s under President Kim Young-sam. For Yoon, it was important for South Korea to improve its competitive edge in high value-added service industries. ${ }^{9}$

Second, the Roh government believed that the KORUS FTA had the potential to improve not only economic ties but also overall diplomatic and security relations between Seoul and Washington. In light of the volatile security outlook in Northeast

7. Worries were expressed in Japan that a prospective US-South Korean accord could put Japan at a competitive disadvantage in the US market. Such recognition might motivate Japan to seek an FTA with the United States, and this could in turn affect China's interest in an FTA with the United States.

8. A presidential speech delivered to the Korea Chamber of Commerce and Industry, March 28, 2006. http://news.naver.com/news/read.php?mode=LOD\&office_id=023\&article_id= 0000178504 .

9. A speech delivered to a conference organized by the Association of Junior High and High School Teachers, Jeju Island, July 24, 2006. 
Asia-China's growth, Japan's normalization, and most importantly North Korea's nuclear adventurism - the Roh government had few options but to strengthen its ties with the United States. Cementing diplomatic ties with the United States is strategically important because South Korea's future lies in coordinating with the United States to ensure the peaceful resolution of the current North Korean nuclear crisis. ${ }^{10}$ The KORUS FTA was expected to have pacifying effects on the Korean peninsula as well as in East Asia as a whole.

The Roh government thought that the KORUS FTA would significantly bolster diplomatic and security relations between the two traditional allies. It was considered necessary to remedy the deteriorating bilateral relationship. Since his inauguration, President Roh has repeatedly argued that it was time for South Korea to turn the bilateral relationship into a more equal one. The Roh government made clear that the United States should not impede South Korea's attempt at improving the inter-Korean relationship under the guise of the sunshine policy, which strained the robustness of the alliance. The KORUS FTA was seen as a way to restore the Korea-U.S. alliance.

Third, the Roh government attempted to incorporate North Korea into the regional and global economy with the KORUS FTA. In negotiations, not just with the United States but with all potential FTA partners, the Roh government tried to insert a special provision about the rules of origin for products made by South Korean companies in Gaeseong in North Korea; it succeeded in part in FTAs with Singapore, ASEAN, and the EFTA. The Roh government expected that North Korea's increased economic integration into the regional and global economy would ultimately lead to a soft landing for the North's economy, easing uncertainty on the Korean peninsula.

\section{CONCLUSION: DIVERSE ECONOMIC-SECURITY LINKAGE STRATEGIES}

While FTAs have mushroomed in East Asia since 2000, East Asian countries have pursued FTAs not merely to increase their economic interests. In many cases, they have attempted to link FTAs to broader security considerations. However, they have demonstrated markedly diverse ways of accomplishing this, depending on their primary economic and security imperatives as well as their domestic political situations. For China and Japan, strategic rivalry for regional leadership in East Asian is a primary factor, facilitating both countries to compete to sign FTAs with ASEAN. China was

10. South Korea had to follow the path that China and Japan set as it signed an FTA with ASEAN. 
eager to assure neighboring countries, particularly Southeast Asian countries, of its peaceful rise. From China's standpoint, an FTA with ASEAN was an effective means to allay their growing security concern as well as to stop them from aligning with the United States.

China's preemptive move accelerated Japan's efforts to drastically change its strategy from pursuing FTAs with individual countries to pursuing an FTA with ASEAN. Japan also attempted to forge ties with extra-regional powers such as Australia to counter the growing influence of China. However, afraid of political opposition from domestically entrenched agricultural interests, the Japanese government could not extend this linkage strategy to the United States.

Singapore also aggressively seeks FTAs with major powers, inside and outside the region, and has signed FTAs with China, Japan, and the United States. Because its immediate security concern is mainly with neighboring countries with different cultural traditions, Singapore tries to attract as many great powers as possible into Southeast Asia. The Singapore government believes that its growing economic interdependence with great powers will reduce its security vulnerability as the great powers would favor a stable regional order.

South Korea's linkage strategy is unique in East Asia, given that it successfully transformed a security alliance into a comprehensive alliance. With its ambitious regional vision in trouble, the Roh government regarded FTAs as a more effective mechanism for realizing its strategic goals. The KORUS FTA vividly demonstrates the emergence of South Korea's linkage strategy. The Lee Myung-Bak government further strengthened this strategy, emphasizing the importance of economic and security ties with the United States. Recognizing that tension in the Korean-US alliance had significantly increased under the previous (Roh) government, the Lee government presented the KORUS FTA to the National Assembly, despite vehement oppositions from civil activist groups and opposition parties. Moreover, it would have been impossible for South Korea to renegotiate the KORUS FTA from a purely economic point of view.

The examination of individual countries' linkage strategies reveals interesting points. First, strategic competition between China and Japan facilitated the emergence of linkage strategies in East Asia. China's and Japan's security considerations have prevented a China-Japan FTA, thereby blocking the formation of an East Asian FTA. As a result, both countries have competed to attract Southeast Asian countries as their FTA partners, which would greatly help them take regional leadership. China, with the benefit of a highly centralized policy-making structure, has moved ahead of Japan in this race. China's attempt at an FTA with ASEAN was intended not just to assuage Southeast Asian countries' fear of the economic rise of China, but also to place Japan on the defensive diplomatically. 


\section{REFERENCES}

Aggarwal, V. K. 2006. Bilateral trade agreements in the Asia-Pacific: Origins, evolution, and implications. London: Routledge.

Aggarwal, V. K., \& Koo, M. 2007. Beyond network power: The dynamics of formal economic integration in Northeast Asia. The Pacific Review, 18(2): 189-216.

ASEAN (Association of Southeast Asian Nations). 2009. Joint declaration of the heads of state/government of the Association of Southeast Asian Nations and the People's Republic of China on strategic partnership for peace and prosperity. http://www.asean.org/15265.htm.

. 2010. The ASEAN Secretariat. http://www.aseansec.org/68.htm.

Baldwin, R. 1993. A domino theory of regionalism (NBER Working Paper No. W4465). Cambridge, MA: National Bureau of Economic Research.

Business Times, 2001, January 15.

Cai, K. G. 2004. Chinese changing perspective on the development of an East Asian free trade area. The Review of International Affairs, 3: 584-599.

Capling, A. 2008. Preferential trade agreements as instruments of foreign policy: An Australia-Japan free trade agreement and its implications for the Asia Pacific region. The Pacific Review, 21(1): 27-43.

Chosun Ilbo. 2006. January 26.

Cooper, W. H., \& Manyin, M. E. 2007. The proposed South Korea-U.S. free trade agreement. CRS Report for Congress. Order code RL33435. Washington, D.C.: Congressional Research Service.

deLisle, Jaques. 2006. Free trade areas: Legal aspects and the politics of U.S., PRC, and Taiwan participation. Philadelphia, PA: Foreign Policy Research Institute. http://www.fpri.org/pubs/20061110.asia.delisle.freetradeareasusprctaiwan.html.

Feinberg, R. 2003. The political economy of United States' free trade arrangements. World Economy, 26(7): 1019-1040.

Government of Singapore. 2010. Singapore FTAs. http://www.fta.gov.sg/sg_fta.asp.

Green, M. 2010. American aims: Realism still prevails over community idealism. Global Asia, 5(1): 32-36.

Grieco, J. 1997. Systemic sources of variation in regional institutionalization in Western Europe, East Asia, and the Americas. In E. D. Mansfield \& H. V. Milner (eds.), The political economy of regionalism (pp. 164-187). New York: Columbia University Press.

Gruber, L. 2000. Ruling the world: Power politics and the rise of supranational institutions. Princeton, NJ: Princeton University Press.

Hamilton-Hart. 2000. The Singapore state revisited. The Pacific Review, 12(2): 195-216. 
Hemmer, C., \& Katzenstein, P. J. 2002. Why there is no NATO in Asia: Collective identity, regionalism, and the origins of multilateralism. International Organization, 56(3): 575-607.

Higgott, R. 2004. US foreign economic policy and the securitisation of globalisation. International Politics, 41: 147-175.

Ikenberry, G. J. \& Mastanduno, M. 2003. International relations theory and the AsiaPacific. New York: Columbia University Press.

Institute of International Trade of Korea. 2011. The current status of FTA expansion and its implications. Trade Focus, 10(19): 1-18.

Jiang, Y. 2010. China's pursuit of international political economy: Is China exceptional? Review of International Political Economy, 17(2): 238-261.

Joongang Ilbo. 2007. April 6.

Katada, S., \& Solis, M. 2007. Understanding East Asian cross-regionalism: An analytical framework. Pacific Affairs, 80(2): 229-257.

Katzenstein, P. J. 1997. Introduction: Asian regionalism in comparative perspective. In P. Katzenstein and T. Shiraishi (eds.), Network power: Japan and Asia. Ithaca, NY: Cornell University Press.

Koo, M. 2009. South Korea's FTA: Moving from an emulative to a competitive strategy. In M. Solis, B. Stallings, \& S. N. Katada (eds.), Competitive regionalism: FTA diffusion in the Pacific Rim (pp. 181-197). New York: Palgrave.

Kurlantzick, J. 2008. Charm offensive: How China's soft power is transforming the world. New Haven, CT: Yale University Press.

Kwei, E. 2006. Chinese trade bilateralism: Politics still in command. In V. K. Aggarwal \& S. Urata (eds.), Bilateral trade agreements in the Asia-Pacific: Origins, evolution, and implications (pp. 117-139). London: Routledge.

Lee, S. 2006. Singapore trade bilateralism: A two-track strategy. In V. K. Aggarwal \& S. Urata (eds.), Bilateral trade agreements in the Asia-Pacific: Origins, evolution, and implications (pp. 184-205). London: Routledge.

. 2007. The evolution of South Korea's trade policy and FTA. Journal of Korean Political and Diplomatic History, 29(1): 103-134 (in Korean). . 2009. Production networks and changes in Japan's FTA strategy. Korean Political Science Review, 43(3): 219-241.

Lee, S., \& Koo, M. 2006. South Korea's multi-track FTA strategy: Moving from reactive to proactive. Paper presented at the annual meeting of the American Political Science Association, August 31-September 3, Philadelphia, PA.

Leifer, M. 2000. Singapore's foreign policy: Coping with vulnerability. London: Routledge.

Low, L. 2001. The Singapore developmental state in the new economy and polity. The 
Pacific Review, 14(3): 411-441.

METI (Ministry of Economy, Trade, and Industry of Japan). 2008. White paper on international economy and trade. Tokyo: Author.

Mochizuki, M. M. 2009. Political-security competition and the FTA movement: Motivations and consequences. In M. Solis, B. Stallings, \& S. N. Katada (eds.), Competitive regionalism: FTA diffusion in the Pacific rim (pp. 54-73). New York: Palgrave.

MOFA (Ministry of Foreign Affairs of Japan). 2012. Free trade agreement (FTA) and economic partnership agreement (EPA). http://www.mofa.go.jp/policy/economy/ fta/index.html.

MOFAT (Ministry of Foreign Affairs and Trade, Republic of Korea). 2011. Ministry of Foreign Affairs and Trade. http://www.fta.go.kr/new/index.asp.

MOFCOM (Ministry of Commerce of the People's Republic of China). 2012. China FTA network. http://fta.mofcom.gov.cn/english/index.shtml.

MOFTA (Ministry of Foreign Affairs and Trade of Korea). 2006. Key initiatives of year 2006. Seoul: Author.

Moon, C., \& Rhyu, S. 2010. Rethinking alliance and the economy: American hegemony, path dependence, and the South Korean political economy. International Relations of the Asia-Pacific, 10: 441-464.

Mulgan, A-G. 2005. Where tradition meets change: Japan's agricultural politics in transition. Journal of Japanese Studies, 31(2): 261-298.

Pang, E. 2007. Embedding security into free trade: The case of the United StatesSingapore free trade agreement. Contemporary Southeast Asia, 29(1): 1-32.

Pempel, T. J. (ed.). 2005. Remapping East Asia: The construction of a region. Ithaca, NY: Cornell University Press.

2006. The race to connect East Asia: An unending steeplechase. Asian Economic Policy Review, 1(2): 239-254.

. 2010. Soft balancing, hedging, and institutional Darwinism: The economicsecurity nexus and East Asian regionalism. Journal of East Asian Studies, 10(2): 209-238.

Ravenhill, J. 2008. The move to preferential trade on the western Pacific rim: Some initial conclusions. Australian Journal of International Affairs, 62(2): 129-150.

. 2010. The "new East Asian regionalism": A political domino effect. Review of International Political Economy, 17(2): 178-208.

Sally, R. 2006. Free trade agreements and the prospects for regional integration in East Asia. Asian Economic Policy Review, 1(2): 306-321.

Shirk, S. 2010. American hopes: An agenda for cooperation that serves U.S. interests. Global Asia, 5(1): 27-31. 
Sohn, Y., \& Koo, M. 2011. Securitizing trade: The case of the Korea-US free trade agreement. International Relations of the Asia-Pacific, 11.

Solis, M. 2009. Japan's competitive FTA strategy: Commercial opportunity versus political rivalry. In M. Solis, B. Stallings, \& S. N. Katada (eds.), Competitive regionalism: FTA diffusion in the Pacific Rim (pp. 198-215). New York: Palgrave.

Straits Times. 2003. March 3.

Terada, T. 2009. Competitive regionalism in southern Asia and beyond. In M. Solis, B. Stallings, \& S. N. Katada (eds.), Competitive regionalism: FTA diffusion in the Pacific Rim (pp. 161-180). New York: Palgrave.

2011. Japan and management of the transatlantic crisis: Interaction and domestic struggles. Contemporary Politics, 17(2): 201-215.

Weber, D. 2001. Two funerals and a wedding: The ups and downs of East Asian regionalism in East Asia and Asia-Pacific after the financial crisis. The Pacific Review, 14(3): 339-372.

Wesley, M. 2008. The strategic effects of preferential trade agreements. Australian Journal of International Affairs, 62(2): 214-228.

Yang, M., \& Heng, S. 2010. Promoting China-ASEAN economic cooperation under CAFTA framework. International Journal of China Studies, 1(3): 667-684.

Yoshimatsu, H. 2006. The politics of Japan's free trade agreement. Journal of Contemporary Asia, 36(4): 479-499.

Zhao, S. 2010. China's approaches toward regional cooperation in East Asia: Motivations and calculations. Journal of Contemporary China, 20(6): 53-67. 